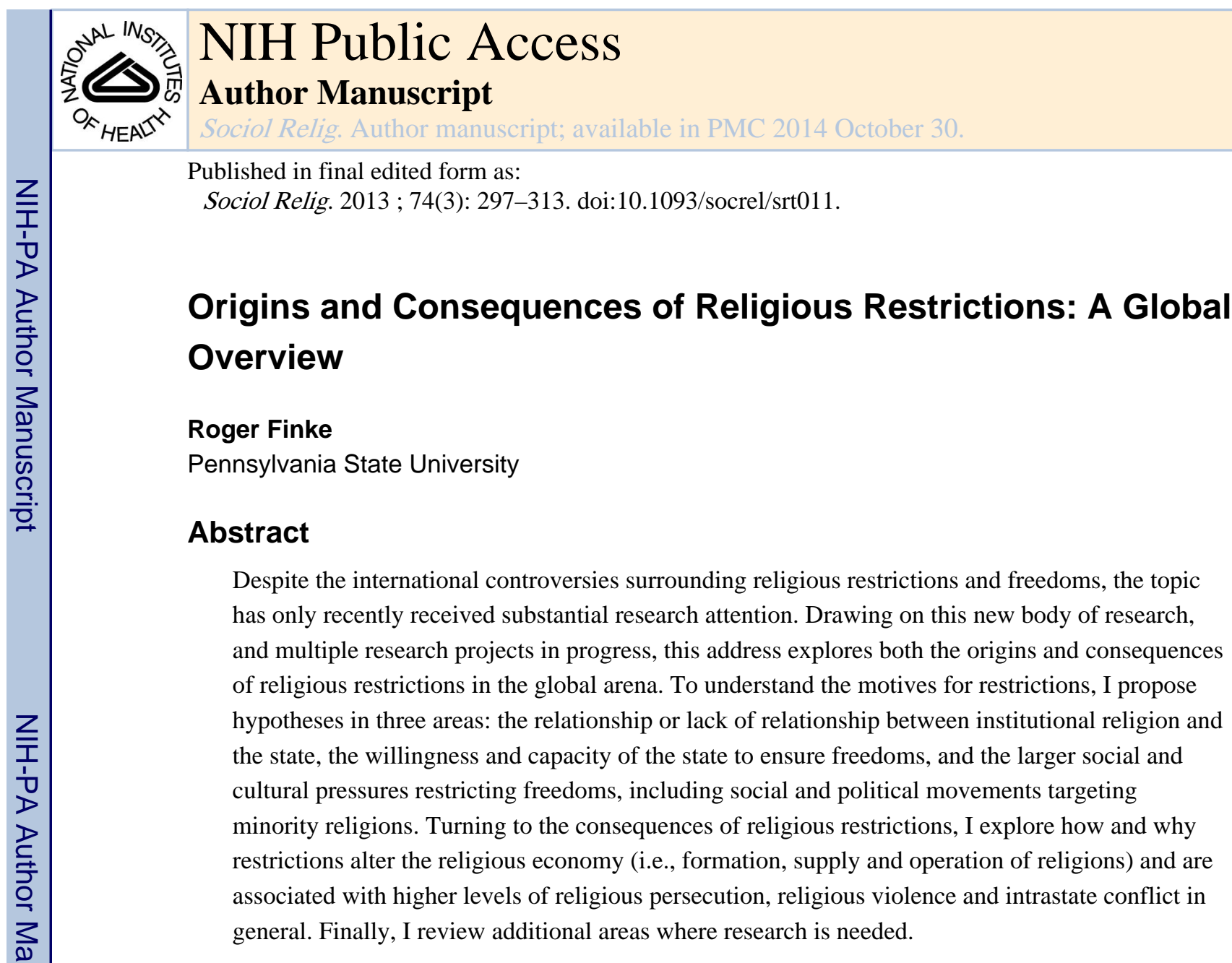

When an unlikely alliance of religious and human rights groups advocated for improving international religious freedoms in the mid-1990s, they described the freedoms as the overlooked "orphan of human rights" (Hertzke 2004, p. 69). But if religious freedoms were frequently overlooked in policy, they were virtually ignored in international studies. Prior to 2000 , there were no systematic data collections on religious freedoms and few studies attempted to understand either the origins or the consequences of these freedoms. Indeed, even for the heavily studied topic of international social conflict, little attention was given to religion and even less was given to religious freedoms. Samuel P. Huntington's "Clash of Civilizations" thesis is the most notable exception, but this approach gained little support from other social scientists and his silence on religious freedoms spoke volumes for many (Huntington 1996).

Despite this silence, religious freedoms are of both theoretical and substantive importance for those who study religion. Because denying religious freedoms represent regulations or restrictions placed on religion, these denials lie at the heart of religious economy arguments. But the theoretical importance of religious freedoms is not limited to religious economy arguments and the potential substantive consequences go far beyond religion. Whether the theoretical discussion involves civil liberties, economic development, social conflict or a long list of other topics, the restrictions placed on these freedoms have potential consequences that need to be understood. 
Since 2000 there has been a flurry of data collections on religious restrictions and a new body of research has begun to emerge. Drawing on these new sources, including my own work with Brian Grim, Jaime Harris and Robert Martin, I want to explore both the origins and the consequences of religious freedoms in the global arena.

\section{Beyond America}

This isn't the first time that I have sought to explain the origins and consequences of restrictions on religion. More than twenty years ago, I published a paper entitled "Religious Deregulation: Origins and Consequences" (Finke 1990). This paper drew on historical evidence to tell the story of how religious freedoms arose in America. The paper explained that in most colonies a religious tolerance arose more out of necessity than principle and the eventual turn to religious liberties was promoted by an unlikely alliance of political rationalists, such as Thomas Jefferson, and religious sect leaders such as the Baptist pastor Isaac Backus. The sect leaders wanted the state out of religion's domain and the rationalists wanted the church out of the state's arena. The alliance was tenuous and short-lived, but it clearly illustrated the mixed motives for supporting religious freedoms.

The paper also outlined some of the consequences of deregulating religion. For the individual, religious deregulation allowed for a freedom of choice without penalty or increased costs. For religious organizations, they could compete on a level playing field where startup costs were low and the opportunity for innovation was high. Finally, for the religious market as whole, regulatory agencies were abolished and an increased pluralism better served the diverse religious demand. In short, I argued that religious freedoms increased the supply of religion by changing the incentives and opportunities for religious producers (churches, preachers, revivalists, etc.) and the viable options for religious consumers (church members). All of this resulted in what Rodney Stark and I called the churching of America.

I want to expand on this initial explanation in two key areas. First, I want to move beyond the United States. When working with a single case it is obviously impossible to explain variation and as a result some have suggested that the principles reviewed are distinctively American (Warner 1993). Second, when exploring the consequences, I want to move beyond religion. In particular, I want to look at the relationships religious freedoms hold with multiple measures of social conflict. Although the potential for conflict is often cited as a need for restricting freedoms, the consequences of increased restrictions are often more conflict.

To avoid confusion I want to begin with a few definitions. I will define religion as a system of beliefs, symbols and practices concerned about the nature and workings of the supernatural and about ultimate meaning. Whereas some define religion based on the functions it performs for individuals or for society at large, my definition confines religion to beliefs and practices that are based on supernatural assumptions. This helps to distinguish religion from secular ideologies, science and other forms of culture that may serve many of the same functions of belonging and belief that religion performs. By extension, I define religious groups as collectives that promote religious beliefs, symbols and practices. 
Building on these two definitions, religious freedom refers to the unrestricted practice, profession and selection of religion.

\section{The Origins of Religious Restrictions}

Measuring religious restrictions has been a challenge. Approximately fifteen years ago, when I was first looking for cross-national measures on religious restrictions, I thought national constitutions might serve as a proxy. I was wrong. After reviewing multiple constitutions, I quickly found a wide gap between promise and practice. Religious freedoms were routinely promised, even in countries where the practice was routinely denied. More recently when the Association of Religion Data Archives (www.theARDA.com) conducted a systematic data collection on religious restrictions, Brian Grim and I found that the chasm was even greater than I expected. Only 9 percent of the nations failed to provide assurances of religious freedom; yet 86 percent of the nations had at least one law restricting religious freedoms and 38 percent had four or more such laws. Additional collections at the Association of Religion Data Archives (Grim and Finke 2006), as well as collections by Freedom House (Marshall 2000), the Religion and State Project at Bar Ilan University (Fox 2008; 2011), and the Pew Forum on Religion and Public Life (2009) have all confirmed these findings. This raised several perplexing questions about the motives, movements and institutions involved in restricting religious freedoms. One of the obvious questions is what are the motives of the state for restricting or supporting religious freedoms?

\section{State's Motives for Restricting or Supporting Religious Freedoms}

One of the most common motives for restricting freedoms arises from the state's relationship with the dominant religion or group of religions. As Anthony Gill (2008) explains in The Political Origins of Religious Liberty the state often forms an alliance with religion in an effort to enhance political stability through increased political support, more effective control of the dominant religion, and increased political and ideological compliance. ${ }^{1}$ Institutional alliances can imbue religious authority to most institutions in the country, as in Iran, or they can be based on past traditions and offer little formal authority, as in many Latin American countries. Even nations that are officially atheist, such as contemporary China, form alliances with select religions. These alliances allow them to more effectively control the activities of the favored religions and to more heavily regulate those not condoned by the state (Yang 2006, 2012; Richardson and Edelman 2004). Yet these alliances with religion typically come with a price. The state is often expected to favor the established religion and to regulate religious and cultural competitors. Gill's propositions and the work of others suggest that when states form alliances with select religion(s), restrictions on religious freedoms will increase.

However, even when no alliances are formed with the dominant religions, the state often has motives for denying freedoms. The most obvious examples are communist governments proposing atheism as an official ideology. Mao's Cultural Revolution (1966-1979) or the former Soviet Union represent extreme outcomes of this position, where the state attempts to eliminate religion (Yang 2006; Froese 2004, 2008). But even when the state holds no

\footnotetext{
${ }^{1}$ See Gill (2008) for an extended discussion on this topic.
} 
competing ideology, the formal organization and the teachings of a religious group can be viewed as a political threat or competitor. Thus, when the state views religions as offering ideological or political alternatives, the state's restrictions of religious freedoms will increase.

Perhaps the most common state motive, however, is restricting minority religious groups because there are strong cultural and religious pressures to do so. My recent work with Brian Grim and Robert Martin consistently finds that the social and cultural pressures against minority religions are a strong predictor of the restrictions enacted by the state, regardless of the controls entered. We find that religious groups are often charged with being a danger to public welfare. Even stable democracies, have accused religious groups with using "brainwashing" or "mind control" to secure the loyalty of members (Richardson and Introvigne 2001). In 2006, an official report to France's prime minister explained that the "sects" create a "condition of destabilization, disorientation, and vulnerability" and then use reinforcement techniques to reconstruct individuals' personalities (Roulet 2006: 23). Although a long line of research refutes the religious minorities' capacity for "mind control," "brainwashing" or personality reconstruction, the media, general public and even state agencies continue to harbor such fears. ${ }^{2}$ As a result, even when states form no religion alliances and religions pose no political threat, the state can still hold motives for restricting religious freedoms: When cultural and social pressures arise against select religions, the state's restrictions on religious freedoms will increase.

Finally, it is important to recognize that states can hold economic and political motives for reducing the level of restrictions on religion. In the case of colonial America, toleration of religious diversity became a necessity for making many of the early colonies profitable. Likewise, the nations relying heavily on expatriate workers, such as the United Arab Emirates, must find ways to tolerate other religions. Nations also face global political pressures to respect basic civil rights. These economic and political pressures seldom result in full freedoms for all religions, but the pressures often result in formal statements of support for religious freedoms and lead to a reduction in the most severe restrictions. When support for religious freedoms offer increased revenue, economic production, or stronger political alliances, political leaders will profess more support for religious freedoms and the level of restrictions often declines. These same pressures also might explain why constitutional promises of religious freedom are so common (despite the lack of practice) and why the constitutional clauses so frequently mimic common global standards. When appeasing global pressures, the constitution becomes the public document for all to see.

Thus, the motives for states restricting or supporting religious freedoms are many and varied. States can restrict freedoms in an effort to support the religion(s) that hold an alliance with the state. Or the state might impose restrictions because religions are perceived challenging the state's ideology, threatening government stability, and being a potential

\footnotetext{
${ }^{2}$ The research finds that the vast majority of the groups are not a danger to the individual or society and none hold the powers of mental manipulation or brainwashing, despite the high level of membership commitment to the group. See, for example: Richardson (2004); Shupe and Bromley (1980); Barker (1984); Stark and Bainbridge (1985).
} 
harm to public order and the welfare of local citizens. Finally, states can have economic and political motives for supporting such freedoms.

Each of the motives just reviewed suggests that the state is often intentional in denying or supporting freedoms. In many cases, however, the state is simply unwilling, unable or disinterested in protecting religious freedoms.

\section{The State's Failure to Protect Religious Freedoms}

Virtually all of the freedoms listed in the UN's Universal Declaration of Human Rights can offend or threaten a cultural majority, and, as a result, all require state support to ensure the freedom is protected. Religious freedoms are no exception. Like other freedoms, protecting religious freedoms can be both inconvenient and costly. Even when the state lacks explicit motives for restricting religious freedoms, the state often allows restrictions to arise because it lacks either the motive or the ability to protect such freedoms.

For some countries, constitutional promises were seemingly never intended to support such freedoms. Indeed, promises of religious freedom are sometimes nullified by other clauses in the same constitution. For example, Article 2 of the 2004 Afghanistan constitution states that all religions "are free to exercise their faith and perform their religious rites within the limits of the provisions of law" and Article 3 explains that "no law can be contrary to the beliefs and provisions of the sacred religion of Islam." 3 In other cases, promises of freedom are negated by legislation or are simply too vague to clearly enforce. But even when the constitutional clauses are clear and religious freedoms are explicitly promised, there are no assurances that freedoms will be protected. The state must be held accountable for enforcing these promises and there must be mechanisms and institutions capable of doing so.

At the most basic level, the state must be capable of protecting the constitutional freedoms. When the state is incapable of enforcing religious freedoms, restrictions on these freedoms will rise. Even when assurances of freedom are clearly stated, the state must have the institutional capacity to protect such freedoms. When the state fails to monitor, enforce and protect these freedoms, the door is open for others to enact their will and to deny these freedoms.

Along with being capable, the state also must be held accountable for protecting these freedoms. Democracy is typically treated as a panacea for ensuring that the state delivers on promises of civil liberties, with free, fair, and open elections being identified as one of keys. This suggests that: when a country has free, fair and open elections, the state's restrictions on religious freedoms will tend to decline. I agree that open and free elections remain an important avenue for holding political leaders accountable, but they often fail to protect minorities. Following Alexis de Tocqueville's lead, political scientists have long warned about the "tyranny of the majority." When looking at the freedoms in a young America, de Tocqueville (1945, p. 270-271) cautioned that the "main evil" he found in this new system was not the "excessive liberty" that most Europeans feared, but the "inadequate

\footnotetext{
${ }^{3}$ Reviewed on the Association of Religion Data Archives (theARDA.com) on August 3, 2012. http://www.thearda.com/ internationalData/countries/Country_1_6.asp
} 
securities ... against tyranny [of the majority]." In the case of religious freedoms, a series of recent elections have demonstrated that majority rule does not ensure freedoms for all. Because a majority might agree that minority religions should be restricted, even free, fair and open elections do not ensure freedoms.

Moving beyond elections I argue that an independent judiciary is especially crucial for protecting freedoms and holding the state accountable. An impartial and independent judiciary offers guarantees of minority rights when such rights are protected in law and provides an institutional avenue for ensuring that these rights are upheld. ${ }^{4}$ Past attention to the judiciary, including my own, has often focused too narrowly on the enactment of various versions of Sharia law, or other forms of religious law. This narrow focus has distracted from the more general principles explaining the relationship between religious freedoms and the courts. Robert Martin and I are finding that the level of independence a judicial system holds from other state and religious institutions is a powerful predictor of religious freedom. In fact, the strong bivariate relationship between religious restrictions and the nation's Muslim population fades to insignificance once we control for the independence of the judiciary. We find that when religious freedoms are supported by an independent judiciary, restrictions on religion are reduced. Government effectiveness, open and free elections, and an independent judiciary all hold strong correlations with religious freedoms, but it is the independent judiciary that proves the most powerful predictor when multiple controls are entered.

Thus, even when the state has few motives for denying freedom and holds no strategy for restricting religious freedoms, the inaction of the state can lead to high levels of restrictions. When the state is weak and the judiciary is embedded within other government or religious institutions, the tyranny of the majority and the actions of religious, political and social movements can quickly deny the religious freedoms of others.

\section{Religious, Social and Cultural Motives for Restricting Religion}

To fully understand the sources for restricting religious freedoms, we need to look beyond the state at religious, social and cultural groups restricting religious freedoms. Not only do these sources spur increased restrictions by the state, they also impose restrictions on religious freedoms independent of the state. We find that when secular, cultural, social and religious groups are mobilized against religious minorities, restrictions on religious freedoms will increase.

We have found that many national and cultural identities are so closely interwoven with or against selected religions that ensuring religious freedoms for all is perceived as challenging the cultural identity as a whole. From informal cultural pressures to well-organized religious, social and political movements, efforts are made to stake out cultural claims and to prevent or prod cultural change; actions that serve to reduce the freedoms of the minority and less powerful religious groups. Sometimes these groups work within the confines of

\footnotetext{
${ }^{4}$ See James T. Richardson (2006) for a discussion of the variations in legal systems and how it is related to religious freedom, including the autonomy of the judicial system. See Wybraniec and Finke (2001) for research on the significance of court decisions for religious minorities.
} 
formal political structures and sanctions, other times they take actions independent of the state to restrict freedoms and even initiate violence.

The motives for these pressures are many. Because the relationship between religion and culture is often complex, lengthy and tightly entwined, dominant religious and social groups can appeal to the history and culture of their country as motivation for denying religious freedoms and even justifying violence. For some countries the dominant religion serves as a source of national identity or cultural unity; allowing religious challengers equal status is viewed as threatening the larger collective. For others, religion provides the moral foundation or legitimacy for judicial, political and social organizations and leaders, with alternative religions serving to threaten this order. Finally, pressures can also arise from secular groups, such as Marxist political groups, seeking to curb the influence of any religion.

India offers an obvious example of social and cultural pressures calling for more restrictions on religion. The Sangh Parivar or Hindutva organizations in India strive to define India as a Hindu nation and to promote Hindu identity and nationalism. Many of the organizations openly discriminate against other religions and they restrict the ability of other groups to speak about their religion or worship in public, with several groups leading vigilante actions against religious minorities (Hibbard 2010; Nandy et al. 1995). Although the national government places few restrictions on religious freedoms, the failure to protect minority religions has resulted in restrictions being imposed by other groups as well as periodic violence resulting from attempts to impose or resist such restrictions (US Department of State 2010). These cultural and social pressures are especially powerful at the local level, influencing both formal and informal sanctions.

These pressures and motives for restricting religion also will vary based on the tensions between religions and cultures within a society. Samuel Huntington has argued that religion is often the foundation of major civilizations and cultural identities. As such, it also serves as the basis for clashing civilizations and cultures. Although I disagree with Huntington's conclusion that multiple civilizations and cultural identities will inevitably result in conflict, I do agree that this diversity often leads to increased calls for restrictions -- a conclusion that is strongly supported by my research with Grim and Martin (Grim and Finke 2011; Finke and Martin 2011).

Because the social and political motives for restricting religious freedoms remain high in many countries and the efforts to protect the freedoms are often weak or ineffective, promised religious freedoms are routinely denied. The obvious question that arises is: so what? Does the denial of religious freedoms for minority religions or even all religions have a significant impact? What are the consequences?

\section{The Consequences of Religious Restrictions}

Previous work on the consequences of religious restrictions, or what is commonly called religious regulation, has often focused on religious diversity and vitality. Like so many areas in the sociology of religion, this research has been consumed with uncovering a master secularization trend or refuting its existence. This ongoing attention to secularization has 
often diverted our attention from many interesting and important questions about restrictions. First, how do the restrictions alter the operation of religion within a society, as well as the religious organizations and individuals in those societies? Second, how do these restrictions influence the larger society? This second area, in particular, has received little attention. Each of these questions could easily justify a book-length manuscript, but for this talk I simply want to review a few of the propositions that either have been or should be tested and studied in greater detail.

\section{Consequences for the Religious Economy}

As noted earlier, religious restrictions lie at the heart of the religious economy model. Rodney Stark and I initially used the model to explain the surge in American religious activity following the lifting of restrictions in the eighteenth and nineteenth centuries (Finke 1990; Finke and Stark 1992; 2005) and it has since been used to explain religious change around the globe (Chestnut 2005; Froese 2008; Gill 1994; Iannaccone, Finke, and Stark 1997; Lu 2008; Stark and Finke 2000). In a paper that was published in the Sociology of Religion and later received the 2009 Distinguished Article Award from the Society for the Scientific Study of Religion, Jonathan Fox and Ephraim Tabory (2008) used a massive global data file and concluded that restrictions are "significantly and negatively correlated" with attending religious services. But the consequences of religious restrictions go far beyond changes in worship attendance. At the individual level, as I noted earlier, the restrictions change the incentives and opportunities both for religious producers and consumers. At the organizational and market level the restrictions change how organizations operate and alter the structure of the market. I have written extensively on this elsewhere (Finke 1990; Finke and Stark 1992; 2005; Stark and Finke 2000), so I offer only a few brief comments here. ${ }^{5}$

One of the most significant outcomes of religious restrictions is how they change the supply and diversity of religions available. Chris Scheitle and I have argued that when restrictions are absent, the diversity in supply is a product of two forces: the underlying diversity of religious preferences and the number of potential adherents within an environment (Scheitle and Finke 2009; Finke and Scheitle, forthcoming). ${ }^{6}$ In other words, when facing few external constraints, the diversity of religious suppliers reflects the social and cultural diversity of the area. ${ }^{7}$ Once restrictions are introduced, however, many market niches go unfilled or are underserved. The restrictions often determine who can enter and they inflate operating costs if they do enter. The end result is that the supply of religions no longer reflects the diversity of religious demand. Because religious minorities are the groups most frequently targeted and are also the source of many religious innovations, religious restrictions also tend to curtail new organizational and market developments. As a result, even when restrictions are targeted only at minority religions, they have consequences on how the entire religious market operates and grows.

\footnotetext{
${ }^{5}$ As confirmed by Fox and Tabory, religious restrictions are a strong predictor of religious activity, but do not have a significant impact on religious beliefs when other controls are entered.

${ }^{6}$ See also Lawson and Cragun (2012) for a discussion on the consequences of synchronizing supply and demand.

${ }^{7}$ When constraints do exist, pluralism at the supplier level will be lower, as some or all suppliers are prevented from fulfilling their potential market niche. In turn, pluralism at the consumer level will be lower, as consumers are concentrated in fewer suppliers, owing to decreased choice.
} 
Closely related to restrictions are the subsidies or favors that the state provides for the dominant religion(s). Rodney Stark and I argue that religious monopolies supported by state subsidies tend to be lazy and less efficient, but we also argue that societies with such monopolies tend to be more sacralized (Stark and Finke 2000). By sacralized we mean that there is less differentiation between religious and secular institutions and that religious symbols, rhetoric and rituals are suffused throughout the culture. ${ }^{8}$ This suggests that at the very time when religious activity might be increasing in a nation, the role of religion in many state-related institutions will be in decline.

In short, religious restrictions, as well as subsidies, have consequences that go far beyond the religious institutions and activities being targeted. Although restrictions are most frequently targeted at religious minorities, they alter the entire market structure and revise both how religious institutions operate and whom they serve.

\section{Consequences Beyond the Religious Economy}

The most obvious consequences of religious restrictions are that they curtail the activities of religions. Yet, a small but rapidly growing body of research suggests that the restrictions have consequences that go well beyond religious institutions and activities. Moreover, some of the consequences defy common expectations. For example, religious restrictions are justified as a necessity for curbing violence and maintaining public order, but research finds just the opposite. Social conflict is often a consequence of increased religious restrictions.

The most carefully documented example is religious persecution. Brian Grim and I devoted a paper in the American Sociological Review and a book with Cambridge University Press to explain how and why religious restrictions are so closely related to persecution (Grim and Finke 2007; 2011). We defined religious persecution as physical abuse or physical displacement due to one's religious practices, profession, or affiliation and proposed that to the extent that religious freedoms are denied religious persecution will increase. The evidence was overwhelmingly supportive. We found that government restrictions on religion were the strongest predictor of religious persecution and that the social restrictions enacted by other religions, social movements and the culture as a whole were powerful predictors as well.

This research has now been replicated using other measures of violence and the relationship still holds. When using a more general measure of religiously motivated violence, one where religion could serve as the perpetrator, victim or both, Jaime Harris and I found that religious restrictions remain a powerful predictor of the violence (Finke and Harris 2012). The most notable change was that social restrictions on religion, rather that government restrictions, now held the most direct and powerful relationship with conflict and violence. When extending this relationship to a more general measure of Intrastate Social Conflict, one that goes beyond religiously motivated violence, Robert Martin and I have found that the relationship is slightly attenuated, but remains highly significant (Finke and Martin

\footnotetext{
${ }^{8}$ See Peter Beyer's 2011 Association for the Sociology of Religion presidential address for an extended discussion on the implications of changing religion and state relations for religious engagement and activity.
} 
2012). Regardless of the measure used for social conflict or violence, we find that to the extent that religious freedoms are denied intrastate conflicts increase.

These studies also reveal that the mechanisms through which religious restrictions increase conflict are similar to many other conflicts. First, we are finding that restrictions alter social interactions between religious groups, determining both the quantity and quality of their contacts, and increasing the potential for conflict. One of the most enduring explanations for understanding social discrimination and conflict has been some form of social contact theory. Although many variants of the theory exist, a central thesis is that increasing contact between groups or individuals tends to reduce inter-group conflict. Yet, most versions of contact theory argue that it is not just the quantity of contacts that matters, it is the type of contacts and the social conditions under which the interactions occur that make the difference. ${ }^{9}$ In particular, scholars often point to four sets of conditions for these interactions: equal status; support by authorities; shared goals; and interdependence between groups. The first highlights that even intimate and frequent contact does little to change inter-group conflict if the interactions assume unequal status. The second condition points to the importance of sanctions stemming from formal and informal authority figures that can either facilitate or impede positive interaction; the third and fourth establish the influence of cooperative rather than competitive actions for the attainment of mutually beneficial outcomes.

When applied to religious groups, we can see that religious restrictions serve to violate all of these conditions. To the extent that formal and informal regulations restrict religious groups, their interactions with other groups are often reduced and when they do occur they are neither cooperative nor equal. ${ }^{10}$ When one group holds an advantage or receives privileges above and beyond another group, the chances of social conflict increase. As a result, the theory proposes that when a religious group's interaction with other members of the society is restricted, the probability of religiously motivated prejudice, discrimination, and violence increases. ${ }^{11}$ My initial attempt to test this thesis with Jaime Harris found that government restrictions on religion do contribute to increased social isolation of the religious groups and that social isolation does help to explain increased levels of violence.

Religious restrictions can also alter both how and why religious groups mobilize their membership, serving as another mechanism through which restrictions increase conflict. We find that increased restrictions and reduced social contacts contribute to the formation of social movements and political parties organizing around religion. Some are organized to protest the restrictions of the state, but many are organized to garner political favors or increase restrictions on minority religions. As noted earlier, these restrictions might be enacted through the state or through vigilante action. This leads to yet another mechanism through which religious restrictions work: To the extent that a religious group forms the basis for political parties and social movements, the group's ability to motivate social action

\footnotetext{
${ }^{9}$ For an early presentation of the theory see Allport (1954). For a more recent overview of the theoretical developments and research results, see Pettigrew and Tropp's (2006) "Meta-analytic Test."

${ }^{10} \mathrm{We}$ emphasize the role of government regulations in restricting interaction, but the limited interaction can also result from natural physical barriers or from social barriers placed on one or more the groups.

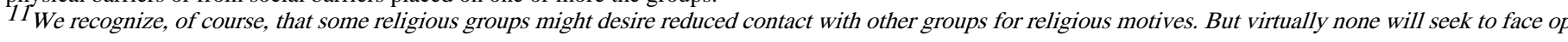


(including religious violence) is increased. When combined with restrictions on religion, this was one of the most powerful predictors of violence in our research.

These initial studies are only a brief start to the research that needs to be done on religion and social conflict. For example, we have still given little attention to the relationship between religion and ethnicity. Scholars know that religion and ethnicity are often closely related, frequently referring to ethno-religious identities, but little cross-national work has been conducted in this area. One obvious research question is: To the extent that religion and ethnicity are closely tied, do religious restrictions heighten ethnic tensions and increase violence between groups? Our initial tests of this thesis found only a weak relationship, but we also were limited by weak measures. A related thesis that goes beyond ethnicity is proposed by James K. Wellman and Kyoko Tokuno (2004, p. 291): the symbolic and social boundaries of religion mobilize individual and group identity in conflict, and sometimes violence, within and between groups. They note that conflict can increase internal unity and result in more effective efforts to mobilize against others. Finally, Fox's recent research has highlighted the importance of knowing the specific targets of the restrictions (e.g., religious minorities). His most recent Religion and State data collection, in particular, will allow us to better understand the consequences of different types of restrictions on religion (e.g., general vs. specific).

The consequences of religious restrictions on religion and social conflict, however, simply scratch the surface of topics needing study. For example, how do restrictions on religion relate to other civil liberties? Brian Grim and I have documented the strong correlations between religious freedom and many other liberties, but what do these correlations mean? We know that some civil liberties can be in conflict with others, such as religious freedoms and the liberties of women, gays and lesbians. How and why does the value given to different liberties vary across countries and over time? Despite these potential conflicts, however, initial reviews of the data would suggest that all boats rise together. When one civil liberty is protected, it enhances the chances of all liberties being protected. Still, there is much to understand on why and when this relationship holds.

We also need to understand how religious freedoms are related to social institutions and to cultural change. For example, how do restrictions on religious freedom alter public discourse or change avenues for political engagement? The level of religious involvement in political discussion and activities varies widely from one nation to another. What are the consequences of this variation? Likewise, how does the religion and state relationship alter economic activity or educational development? Economists and historians have begun to look at how religious freedom and establishment are related to economic activity, but much more needs to be done (Barro and McCleary 2003; Boone, Brouwer, Jacobs, Witteloostuijn, and Zwaan 2012; Kuran 2011).

\section{Conclusion}

At first glance, religious freedoms have much in common with other human rights. In fact, religious freedoms can be viewed as extensions or even redundancies of other liberties. When we look at the United Nations' Universal Declaration of Human Rights (UDHR), we 
find that Article 18 on religious freedom clearly overlaps with the two articles that follow it. The freedom to hold, to teach and to change religious beliefs in public or private might be viewed as a more specific example of the freedom of opinion and expression (Article 19) and the freedom to worship and observe religion publicly overlaps with the freedom of peaceful assembly and association (Article 20). Religion also is listed as a distinctive status category in most covenants and formal statements on human rights. Along with the status categories of race, color, sex, language, social origin and property, religion is assured of receiving all human rights. ${ }^{12}$

Yet, despite the similarities between religious freedoms and other liberties, the enforcement of religious freedoms is frequently complicated by the distinctive relationship religion holds with the larger society. First, religions are typically organized into formal institutions that have the potential for mobilizing popular support and forming alliances with the state. The potential for organizing popular support often threatens the state and results in increased restrictions. Likewise, alliances between the state and dominant religions result in increased pressures to restrict religious competitors. Second, religions can often appeal to the shared history and culture of their country as motives for denying religious freedoms and even justifying violence. Religion is often so infused within the institutions, history and identity of a nation that ensuring religious freedoms for all is perceived as challenging the cultural identity as a whole. These social and cultural pressures can call for increased state restrictions as well as implementing restrictions of their own. In the end, religious freedoms rely on the same institutions as other human rights for support and protection, but religions hold distinctive and complex relationships with the state and the larger culture.

In an attempt to control religion and curb potential conflicts, states have typically increased restrictions on most religions and increased favoritism for a few. Yet, research finds that the restrictions fail to curb conflict. Instead, religious freedoms serve to defuse potential violence and the increased restrictions are associated with increased violence. Restrictions often provide the very conditions needed for religious social conflicts to occur. Along with increasing the grievances of the targeted groups, the restrictions result in decreased contact and increased discrimination across groups. The state's restrictions also embolden the dominant religions to enact even stronger restrictions. In contrast, when freedoms are uniformly secured, the freedoms for even the smallest minority become the freedoms for all. Simply put, I have more motivation to support your religious freedoms when your freedoms are my freedoms.

But the consequences of religious restrictions go far beyond social conflict and the origins are remarkably complex. Many questions remain. I invite you to join in this exploration. ${ }^{13}$

\footnotetext{
${ }^{12}$ The complete wording of Article 2 is as follows: "Everyone is entitled to all the rights and freedoms set forth in this Declaration, without distinction of any kind, such as race, colour [sic], sex, language, religion, political or other opinion, national or social origin property, birth or other status. Furthermore, no distinction shall be made on the basis of the political, jurisdictional or international status of the country or territory to which a person belongs, whether it be independent, trust, non-self-governing or under any other limitation of sovereignty."

${ }^{13}$ Recent data collections by the ARDA and Pew Forum now offer strong measures for social restrictions on religion and the second round of the Religion and State project offers extremely refined measures on religion and the state.
} 


\section{Bibliography}

Allport, Gordon. The Nature of Prejudice. Reading, MA; Addison-Wesley; 1954.

Barker, Eileen. The Making of a Moonie: Brainwashing or Choice. Basil Blackwell; Oxford, United Kingdom: 1984.

Barro, Robert J.; McCleary, Rachel M. Religion and Economic Growth Across Countries. American Sociological Review. 2003; 68(5):760-81.

Beyer, Peter. Socially Engaged Religion in a Post-Westphalian Global Context: Remodeling the Secular/Religious Distinction. Sociology of Religion. 2012; 73:109-129.

Boone, Christophe; Aleid Brouwer, Jan Jacobs; Van Witteloostuijn, Arjen; De Zwaan, Matthijs. Religious Pluralism and Organizational Diversity: An Empirical Test in the City of Zwolle, the Netherlands, 1851-1914. Sociology of Religion. 2012; 73:150-173.

Chestnut, Andrew. Competitive Spirits: Latin America's New Religious Economy. Oxford University Press; New York: 2003.

Finke, Roger. Religious Deregulation: Origins and Consequences. Journal of Church and State. 1990; 32:609-626.

Finke, Roger; Harris, Jaime. Wars and Rumors of Wars: Explaining Religiously Motivated Violence.. In: Fox, Jonathan, editor. Religion, Politics, Society and the State. Oxford University Press; New York, NY: 2012.

Finke, Roger; Martin, Robert R. Presented at the Annual Meeting of the Association for the Sociology of Religion. Las Vegas, NV.: Aug 19. 2011 Ensuring Liberties: Understanding Religious Freedoms and Restrictions..

Finke, Roger; Martin, Robert R. Religious Freedom and Conflict: A Review of the Evidence. A report prepared for the USAID Conflict Management and Mitigation Office. 2012:65. note: add ARDA link.

Finke, Roger; Scheitle, Christopher P. Stolz, Jörg; Usunier, Jean-ClaudeSources of Religious Pluralism: Revisiting the Relationship between Pluralism and Participation. Religions as Brands: The Marketization of Religion and Spirituality. Forthcoming.

Finke, Roger; Stark, Rodney. The Churching of America, 1776-1990: Winners and Losers in our Religious Economy. Rutgers University Press; New Brunswick: 1992.

Finke, Roger; Stark, Rodney. The Churching of America, 1776-2005: Winners and Losers in our Religious Economy. Second Edition. Rutgers University Press; New Brunswick: 2005.

Fox, Jonathan. A World Survey of Religion and the State. Cambridge University Press; New York: 2008.

Fox, Jonathan. Out of Sync: The Disconnect Between Constitutional Clauses and State Legislation on Religion. Canadian Journal of Political Science. 2011; 44:59-81.

Fox, Jonathan; Tabory, Ephraim. Contemporary Evidence Regarding the Impact of State Regulation of Religion on Religious Participation and Belief. Sociology of Religion. 2008; 69:245-271.

Froese, Paul. After Atheism: Religious Monopolies in the Post-Communist World. Sociology of Religion. 2004; 65:57-75.

Froese, Paul. The Great Secularization Experiment: What Soviet Communism Taught Us About Religion in the Modern Era. University of California Press; Berkeley: 2008.

Gill, Anthony J. Rendering Unto Caesar: The Catholic Church and the State in Latin America. University of Chicago Press; Chicago: 1994.

Gill, Anthony J. The Political Origins of Religious Liberty. Cambridge University Press; New York: 2008.

Grim, Brian; Finke, Roger. International Religion Indexes: Governmental Regulation, Government Favoritism, and Social Regulation of Religion.. Interdisciplinary Journal of Research on Religion 2. 2006. Article 1. (http://www.religjournal.com/)

Grim, Brian J.; Finke, Roger. Religious Persecution in Cross-National Context: Clashing Civilizations or Regulated Religious Economies? American Sociological Review. 2007; 72:633-658.

Grim, Brian; Finke, Roger. The Price of Freedom Denied: Religious Persecution and Violence. Cambridge University Press; Cambridge, United Kingdom: 2011. 
Hertzke, Allen D. Freeing God's Children: The Unlikely Alliance for Global Human Rights. Rowman \& Littlefield; Lanham, MD: 2004.

Hibbard, Scott W. Religious Politics and Secular States: Egypt, India and the United States. The Johns Hopkins University Press; Baltimore, MD: 2010.

Huntington, Samuel P. The Clash of Civilizations and the Remaking of World Order. Simon \& Schuster; New York: 1996.

Iannaccone, Laurence R.; Finke, Roger; Stark, Rodney. Deregulating Religion: The Economics of Church and State. Economic Inquiry. 1997; 35:350-364.

Kuran, Timur. The Long Divergence: How Islamic Law Held Back the Middle East. Princeton University Press; Princeton, N.J.: 2011.

Lawson, Ronald; Cragun, Ryan T. Comparing the Geographic Distributions and Growth of Mormons, Adventists and Witnesses. Journal for the Scientific Study of Religion. 2012; 51:220-240.

Lu, Yunfeng. Religious Economy and Chinese Sects. Lexington Books; Lanham, MD: 2008.

Marshall, Paul A., editor. Religious Freedom in the World. Rowman and Littlefield; Lanham, MD: 2000.

Nandy, Ashis; Shikha Trivedy, Shail Mayaram; Yagnik, Achyut. Creating a Nationality: The Ramjanmabhumi Movement and Fear of the Self. Oxford University Press; Delhi, India: 1995.

Pettigrew, Thomas; Tropp, Linda. A Meta-Analytic Test of Intergroup Contact Theory. Journal of Personality and Social Psychology. 2006; 90:751-783. [PubMed: 16737372]

Pew Forum on Religion and Public Life. Global Restrictions on Religion. 2009. Retrieved July 24, 2011 (http://pewforum.org/Government/Global-Restrictions-on-Religion.aspx)

Richardson, James T., editor. Regulating Religion: Case Studies from Around the Globe. Kluwer Academic/Plenum Publishers; New York: 2004.

Richardson, James T. The Sociology of Religious Freedom: A Structural and Socio-Legal Analysis. Sociology of Religion. 2006; 67:271-294.

Richardson, James T.; Edelman, Bryan. Cult Controversies and Legal Developments Concerning New Religious Movements in Japan and China. In: Richardson, James T., editor. Regulating Religion: Case Studies from Around the Globe. Kluwer Academic/Plenum Publishers; New York: 2004. p. 359-380.

Richardson, James T.; Introvigne, Massimo. Brainwashing' Theories in European Parliamentary and Administrative Reports on 'Cults' and 'Sects. Journal for the Scientific Study of Religion. 2001; 40(2):143-168.

Roulet, Jean-Michel. Report to the Prime Minister, 2006, Interministerial Mission of Vigilance and Combat against Sectarian Aberrations. Retrieved July. 2006; 2011; 25 http:// www.miviludes.gouv.fr/IMG/pdf/Report_Miviludes_2006.pdf.

Scheitle, Christopher P.; Finke, Roger. Pluralism as Outcome: The Ecology of Religious Resources, Suppliers, and Consumers. Interdisciplinary Journal of Research on Religion. 2009; 5 Article 7: www.religjournal.com.

Shupe, Anson D.; Bromley, David G. The New Vigilantes: Deprogrammers, Anti-cultists, and the New Religions. Sage Publications; Beverly Hills, CA: 1980.

Stark, Rodney; Sims Bainbridge, William. The Future of Religion: Secularization, Revival, and Cult Formation. University of California Press; Berkeley: 1985.

Stark, Rodney; Finke, Roger. Acts of Faith: Explaining the Human Side of Religion. California University Press; Berkeley, CA: 2000.

Tocqueville, Alexis de. Democracy in America. Vol. 1. Vintage; New York: 1945. 1835.

US Department of State. International Religious Freedom Report 2010: India. 2010. Retrieved July 9 , 2011 (http://www.state.gov/g/drl/rls/irf/2010/148792.htm

Warner, R. Stephen Work in Progress toward a New Paradigm for the Sociological Study of Religion in the United States. American Journal of Sociology. 1993; 98:1044-93.

Wellmann, James K.; Tokuno, Kyoko. Is Religious Violence Inevitable. Journal for the Scientific Study of Religion. 2004; 43:291-296. 
Wybraniec, John; Finke, Roger. Religious Regulation and the Courts: The Judiciary's Changing Role in Protecting Minority Religions from Majoritarian Rule. Journal for the Scientific Study of Religion. 2001; 40:427-444.

Yang, Fenggang. The Red, Black, and Gray Markets of Religion in China. The Sociological Quarterly. 2006; 47:93-122.

Yang, Fenggang. Religion in China: Survival and Revival under Communist Rule. Oxford University Press; New York: 2012. 